\title{
Lexicalization of Motion Event in Persian
}

\author{
Hajar Babai \\ Faculty of Foreign Languages and Literature, University of Tehran, Iran \\ Email: h.babai@ut.ac.ir
}

\begin{abstract}
In this paper we will have a short look at Persian language structure and discuss about expressing change of state and motion in Persian. Persian is considered among languages with a few simple verbs, and most of Persian verbs are compound. We can categorize the Persian verbs indicating motion event as following: 1. PATH is expressed in a non-head framed construction, and the main verb shows the MANNER of motion. Compounds in this pattern are combined verbs and non-separable. 2. PATH is indicated by the main verb (head-framed construction type) and is emphasized or explained in the non-verbal (satellite/non-head) part, and the MANNER of motion comes in the adverb.3. The main verb indicates both PATH and MANNER of motion: Although, it may be considered as an incorporated compound verb in which the prepositional disappears after incorporation. Both head-framed and non-head framed construction of path are available in Persian, but except deictic verbs in which path is specified, in other cases, path is expressed mostly in a nonhead construction type. The main verb almost expresses manner of motion, and path is mentioned in the nonhead part of a clause. Of course, it needs more studies in order to judge and prove whether Persian is a nonhead framed (S-Language) or not.
\end{abstract}

Index Terms-Persian, motion, compound verb, path and manner

\section{INTRODUCTION}

Persian is an Indo-European Language with SOV structure. The most verbs in Persian are compound as there are few simple verbs in this language. I discuss the article "compound verbs in Persian" of Dabir moghaddam (1997) before the main discussion in order to get a general knowledge about the construction of Persian compounds.

Persian is a SOV language. Verbs are marked for tense and aspect and agree with the subject in person and number.

(1) ali be madrese raft- $\varnothing$

'Ali went to school.'

(2) man tă xăne david-am

I until house ran-1S

'I ran to the house.'

Although verbs come at the end of sentence and it is a head-last language, Persian is otherwise head-first as in NounGenitive (Ezafe), Noun-Adjective, and Preposition-Noun. It is observed in the following examples that heads are initial.
(3) barădar-e man
brother-EZ I
'my brother'
(4) doxtar-e zib̆a
girl-EZ pretty

(a) pretty girl

(5) dar xăne

in house

'in the house'

\section{COMPOUND VERBS IN PERSIAN}

Though many traditional grammarians have argued compound verbs in other languages and in Persian, still we don't have a satisfactory treatment of this category in Persian. We may say that compound verb is a verb consists of a nonverbal part and a verb. Non-verbal part may be a noun, adjective, past participle, etc. Persian compound verb is considered as a whole word although its morphological structure is not simple.

Barjasteh (1983) also has discussed Persian compound verbs in his Ph.D. thesis. According to him, compound verbs may be divided into separable and nonseparable ones. In separable compounds, the nominal parts of compounds can take the accusative case marker -ră in a different structure and hence function syntactically as the direct object of their clauses.
(6) hasan az mă [[in
hasan from we this
taqăză]
request
ră $\quad k a r d-\varnothing]$
$\mathrm{OM} \quad \operatorname{did}-3 \mathrm{~S}$

'Hasan made this request to us.' 


$\begin{array}{cclll}\text { (7) } * \text { ali } & \text { [[in } & \text { qadam] } & \text { ră } & z a d-\varnothing] \\ \text { Ali } & \text { this } & \text { step } & \text { OM } & \text { struck-3S }\end{array}$

Actually lots of Persian verbs expressing the motion event are compound and we may consider the same element in those verbs. Here we have a glance at Dabir moghaddam's article (1997) about the lexicalization of compound verb formation in Persian.

Dabir moghaddam (1997, p. 25) gives a suggestion about Persian compound verbs. He defines compound verb as a verb which "is made up of two otherwise independent constituents that form a compound word". He spotlights the formation processes of compounds and makes a distinction between compound verbs formed through combination and those formed through incorporation and believes that these two vary in degree of productivity: "In compounds formed through combination, an adjective, noun, prepositional phrase, adverb or past participle has combined with a verb. In the formation of compound via incorporation, a nominal element functioning as a direct object loses its grammatical ending(s) and some prepositional phrases functioning as adverbs of location lose their preposition and incorporate with the verb. Therefore, in incorporation there is always a corresponding nonincorporated construction."

\section{A. Combination}

Following him compound verbs formed through combination are constituents from a nonverbal element with a verb. This type is constituent of and adjective and an auxiliary, in which the verb can not be used in a separated form and thus no uncombined form of the verb can be considered. This is the kind that Barjasteh (1983) considers it as non-separable compound.The auxiliaries budan 'to be', šodan 'to become' and kardan 'to make' are used in this kind of compound verbs.

delxor kardan annoyed do 'to annoy'

or constituent of noun and verb

(8) qadam zadan foot strike 'to stroll'

A constituent of a prepositional phrase and a verb is another combined compound verb. This type consists of some motion expressing verbs, but mostly is understood metaphorically.

(9) be-donyă ămadan to-world come ' to be born'

(10) dar miăn nahădan in middle put ' to discuss'

Compound verbs formed through combination can be made of an adverb and a verb. Some motion verbs are made through this construction.
(11) forud ămadan
(12) piš kešidan
down come
before draw
' to land'
' to bring forward'

The last type of combined compounds is the compound which includes past participle and passive auxiliaries. These are passive of compound verbs. The auxiliary involved is šodan 'become'. Any transitive verb that may be passivized belongs to this set.
(13) košte šodan
killed become
' to be killed'

Although Dabir moghaddam (1997) separates this kind of verbs as a compound formed through combination, I think it may be considered just as the passive form of simple verbs, as in the above example the active verb is koštan, and just the past participle follows the verb šodan to form the passive verb as the process of formation applies.

\section{B. Incorporation}

Compounds formed through incorporation are those in which direct object or preposition phrase are incorporated with a verb. In Persian when the direct object looses its grammatical endings (e.g., the postposition -ră, the indefinite marker $-i$ ) it may incorporate with the verb and then create an intransitive compound verb which is a conceptual whole. For instance 14 (a) contains an independent direct object qaz $\breve{a}-y e \check{s}-\breve{a} n$ which is incorporated with the verb xord-and in 14(b).

(14)

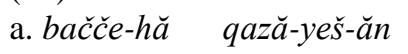
$r a ̆$
child-pl food-his/her-pl
'The children ate their food.'

b. bačče-hă qaz̆a $\quad$ xord-and.

Child-PL food ate-3P

'The children did food eating.'

Incorporation occurs in Persian also in the case of prepositional phrases functioning as adverbs of location also according to Dabir moghaddam (1997). After incorporation the prepositional disappears. Examples (a) and (b) below exemplify this possibility.

(15)

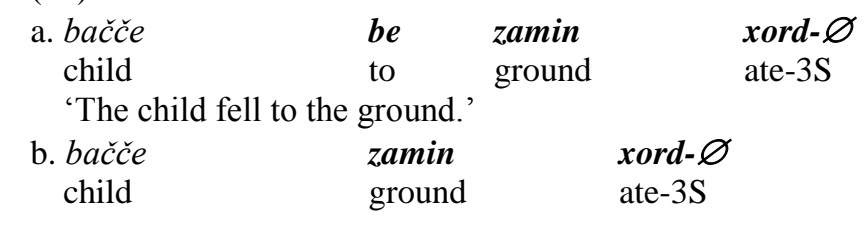


The child fell down.

This kind of incorporation may be observed in expressing the motion event in Persian and it will be discussed later.

\section{PERSIAN PREPOSITIONS}

Prepositions may be divided into two groups: bare prepositions and ezafe prepositions (those which are always used in genitive case). Following are lists of the preposition used in motion expressing, divided according to whether express vector of motion or conformation.

\section{A. Prepositions Which Show Confirmation

$\begin{array}{ll}\text { outside of } & \text { birun-e, xărej-e } \\ \text { inside } & \text { dăxel-e, tu-ye } \\ \text { in front of } & \text { jolo-ye, piš-e } \\ \text { behind of } & \text { pošt-e, pas-e } \\ \text { on, above } & \text { bălăye, ru-ye } \\ \text { under, } & \text { zir-e } \\ \text { between } & \text { bein-e }\end{array}$

These prepositions (except bein-e 'between') may be combined with the verb to constitute a compound verb, and then they lose the form of ezafe, e.g., birun raftan 'to go out, exit'.

\section{B. Prepositions Which Show Vector}

$\begin{array}{ll}\text { from } & a z \\ \text { to } & b e \\ \text { as.far.as } & t a ̆\end{array}$

These prepositions with their following names may come before a motion verb to be the satellite and show the PATH of the motion. Most of them (except be-taraf-e 'toward' appear without ezafe, e.g., tă xăne davidan 'to run until the house'.

\section{EXPRESSING THE MOTION EVENT IN PERSIAN}

Following Talmy (1985) one can distinguish two types of languages -perhaps a universal split- in terms of whether they prefer to express change of state in verbs or in elements associated with verbs. He divides languages to verbframed languages, in which PATH is indicated by the main verb in a clause, and satellite-framed languages, which PATH is given by a satellite to the verb in those languages. These two types of lexicalization pattern entail two types of grammatical construction for motion events. Here we study and discuss this idea in Persian. We explained before that compound verbs in Persian are considered as a whole word, it is difficult to distinguish whether path is mentioned by the verb or the satellite. So we may distinguish two terms for expressing change of states, one head framed construction and the other is non-head framed construction. Still we can not decide about Persian to be one of these two patterns. In this paper after an examination we could have a hypothesis and in the next steps of paper we will try to find out whether Persian is a head framed language or non-head framed language in expressing motion event. First we have a look at Persian verbs describe change of location, the core feature of a motion event.

Here are some Persian verbs which express motion event. As mentioned before in Persian, compound verbs are considered as a whole and we can not say that which part of the verb is the main in those verbs. Anyway, the verbal part of a compound is considered as the head of the clause. Persian motion verbs can be divided as following:

1-The main verb expresses path of motion: (mostly auxiliaries or deictic verbs, except gozaštan 'pass').

$\begin{array}{lll}\text { raftan } & \text { go } & \text { go } \\ \text { ămadan } & \text { come } & \text { come } \\ \text { văred šodan } & \text { enter become } & \text { go into, enter } \\ \text { dăxel šodan } & \text { inside become } & \\ \text { xărej šodan } & \text { outside become } & \text { go out, exit } \\ \text { birun raftan } & \text { out go } & \\ \text { bălă raftan } & \text { up go } & \text { go up, rise } \\ \text { bălă ămadan } & \text { up come } & \\ \text { soud kardan } & \text { rise do } & \text { come down, fall } \\ \text { păin ămadan } & \text { down come } & \\ \text { păin raftan } & \text { down go } & \\ \text { nozul kardan } & \text { falling do } & \text { get across, cross } \\ \text { rad šodan } & \text { pass become } & \\ \text { obur kardan } & \text { pass do } & \\ \text { gozaštan } & \text { pass } & \text { walk } \\ \text { 2-Verbs express manner of motion: } & \text { foot hit(strike) } & \\ \text { qadam zadan } & & \end{array}$




$\begin{array}{lll}\text { piăde-ravi kardan } & \text { on foot-going do } & \\ \text { davidan } & \text { run } & \text { run } \\ \text { parvăz kardan } & \text { flying do } & \text { fly } \\ \text { paridan } & \text { fly, jump } & \text { jump } \\ \text { harekat kardan } & \text { motion do } & \text { move } \\ \text { Verbs express both path and manner of motion: } & \\ \text { reže raftan } & \text { troop go } & \text { troop } \\ \text { piăde raftan } & \text { walking go } & \text { walk }\end{array}$

As it is observed, most of motion verbs are compound, and just a few simple verbs are included. Reviewing the compound verbs, we may find some patterns for construction of these verbs:

(a) (preposition + raftan 'to go'): (Path):

\begin{tabular}{|lll|}
\hline birun raftan & out go & go out \\
\hline tu raftan & inside go & go into \\
\hline bălă raftan & up go & go up \\
\hline păin raftan & down go & go down \\
\hline pas raftan & backward go & go backward \\
\hline piš raftan & forward go & go forward \\
\hline jolo raftan & front go & go forward \\
\hline
\end{tabular}

In this part of compounds, the main verb (deictic verb) refers to PATH and emphasized by the non-head part of the compound (satellite), the preposition which is an adverb here, so the compound verbs formed in this way express the PATH of motion as it is observed above. It is possible also to add the prepositions to the deictic verb ămadan 'come' and have the opposite meaning of above verbs. This kind of verbs can be considered as incorporated compound verbs which occur when prepositional phrase functions as adverbs of location.

(b) (\{N/Adj/Adv $\}+$ raftan 'to go'): (Manner+Path):

\begin{tabular}{|lll|}
\hline răh raftan & road go & walk \\
\hline yurtme raftan & trot go (for horse) & trot \\
\hline piăde raftan & walking go & walk \\
\hline reže raftan & troop go & troop \\
\hline sinexiz raftan & chest crawl go & crawl(like a snake) \\
\hline širje raftan & dive go & dive/plunge \\
\hline
\end{tabular}

This kind of verbs is a different pattern of expressing motion event. As in Persian compounds are considered as a whole word, and in this kind of compounds the former part express the manner of motion and the later indicates the PATH and it is a whole, there is no special emphasize on PATH or MANNER of motion in this verbs. We can use another word by a conjunction referring to the first part of the verb. Also in the following sentence

(16)

sarbăzăn moqăbel-e rahbar reže raftand.

soldier-pl in.front.of-EZ leader troop went-3pl

'soldiers troop in front of the leader.'

there is no special ground for the verb. The compound verb is just expressing the act of trooping as there is no reže ămadan. For more explanation, we may have the word piăde-ravi (\{walking/on foot\} going) 'walking' that can be used in

$\begin{array}{lllllll}\text { Man } & \text { piăde-ravi-ră } & \text { az } & \text { savări } & \text { bištar } & \text { dust } & \text { dăram. } \\ \text { I } & \text { on.foot-going-Acc } & \text { from } & \text { riding } & \text { more } & \text { like } & \text { have-1sg }\end{array}$

'I like walking more than riding.'

Thus we may consider this pattern of verbs as a third type which indicates both PATH and MANNER of motion. Though in this type, the verb is deictic, but the compound verb is used to express the manner of motion.

(c) (noun + kardan 'to do'):

\begin{tabular}{|lll|}
\hline nozul kardan & falling do & descend \\
\hline soud kardan & rising do & ascend, climb \\
\hline obur kardan & passing do & pass \\
\hline harekat kardan & move do & move \\
\hline piăde-ravi kardan & on foot-going do & walk \\
\hline parvăz kardan & flying do & fly \\
\hline
\end{tabular}

(d) ( $\{$ N/Adj $\}+$ šodan 'become' $)$ : 


\begin{tabular}{|l|l|l|}
\hline rad šodan & passing become & pass \\
\hline dăxel šodan & entered become & enter \\
\hline văred šodan & entered become & enter \\
\hline xărej šodan & exited become & exit \\
\hline piăde šodan & on foot become & get off \\
\hline
\end{tabular}

These two kinds of motion compound verbs are constituent of nouns and auxiliaries. As the verbal part of these compounds has no special motional meaning, actually the meaning is understood from the former part of compound (non-head part). Thus in a case the first part refers to manner of motion, compound is understood to be a manner expression of motion, e.g., nozul kardan 'descend' or rad šodan 'pass', and if the first part of compound includes the PATH in its meaning it may be adjusted to be a Path expressing compound, e.g., parvăz kardan 'fly'.

Here are some sentences which include different motion verbs in written Persian.

(18)

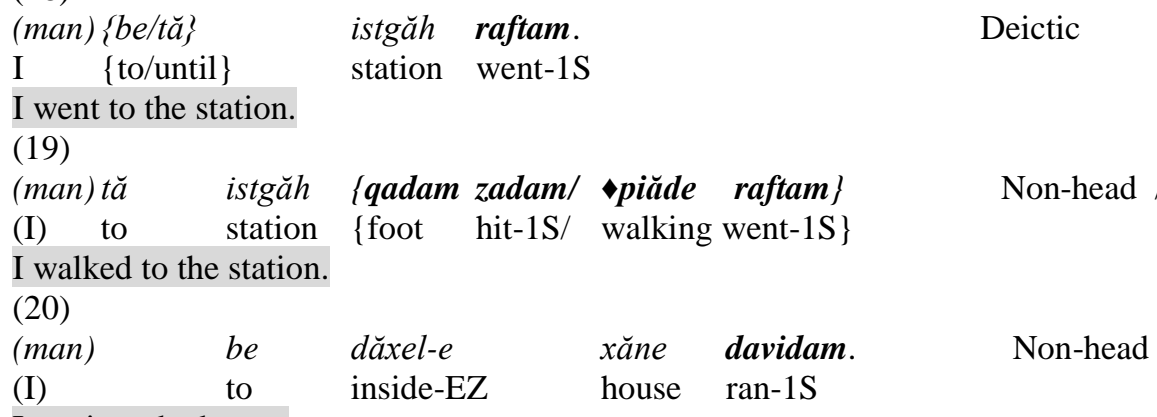

I ran into the house.

(21)

(man) (qadamzanăn) be dăxel-e xăne raftam Deictic

(I) (walking) to inside of house went1S

I walked into the house.

(22)

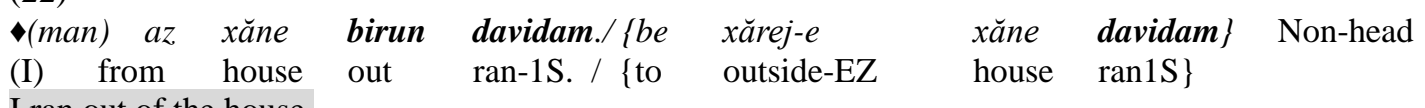

I ran out of the house.

(man)az arze rudxăne gadam-zanăn gozaštam. Head framed

(I) from across-EZ river foot-hitting passed/crossed-1

I walked across the river.

(man)az arz-e rudxăne davăn davăn gozaštam Head framed

(I) from across-EZ river running running passed-1S

I ran across the river.

\begin{tabular}{|c|c|c|c|c|c|c|c|}
\hline (man & $a z$ & tappe & bălă & davidam / \{-tă & nok-e & tappe davidam? & Non-head \\
\hline from & hill & up & $\operatorname{ran}-1 \mathrm{~S}$ & / \{until top-EZ & hill & ran-1S & \\
\hline
\end{tabular}

I ran up the hill.

(26)

(man) tă $\quad\{b a \breve{l a ̆-y e / n o k-e\} ~ t a p p e ~ q a d a m ~ z a d a m ~ N o n-h e a d ~}$

(I) until $\{$ up/top-EZ $\}$ hill foot hit-1S

I walked up the hill.

\begin{tabular}{|c|c|c|c|c|}
\hline (man) & be & $\begin{array}{l}\text { dăxel-e } \\
\text { inside_F7 }\end{array}$ & & negăh \\
\hline
\end{tabular}

I looked into the hall.

(28)

$\begin{array}{llllllll}\text { ४(man) } & \text { yek } & \text { tup } & \text { (ră) be dăxel-e } & \text { jabe partăb kardam. } & \text { Non- head } \\ (\mathrm{I}) \quad \text { a } & \text { ball } & (\mathrm{OM}) & \text { to } & \text { inside-EZ } & \text { box } & \text { throw did-1S } & \end{array}$

I threw a ball into the box.

\section{LEXICALIZATION OF PERSiAn VERBs EXPRESSING Motion EVENTS}

Considering the above points we can categorize the Persian verbs indicating motion event as following:

1. PATH is expressed in a non-head framed construction, and the main verb shows the MANNER of motion. Compounds in this pattern are combined verbs and nonseparable. 


\begin{tabular}{|c|c|c|c|c|}
\hline $\begin{array}{c}\text { (29) (man) } \\
\text { I }\end{array}$ & $\begin{array}{l}\text { tă } \\
\text { as.far.as }\end{array}$ & $\begin{array}{l}\text { bălăy-e } \\
\text { top-EZ }\end{array}$ & $\begin{array}{l}\text { tappe } \\
\text { hill }\end{array}$ & $\begin{array}{l}\text { qadam } \\
\text { foot }\end{array}$ \\
\hline 'I walke & up the hill.' & & & \\
\hline $\begin{array}{l}\text { (30) } t \breve{a} \\
\quad \text { as.far.as }\end{array}$ & $\begin{array}{l}\text { nok-e } \\
\text { top-EZ }\end{array}$ & $\begin{array}{l}\text { tappe } \\
\text { hill }\end{array}$ & $\begin{array}{l}\text { davide } \\
\text { ran-1s }\end{array}$ & \\
\hline
\end{tabular}

2. PATH is indicated by the main verb (head-framed construction type) and is emphasized or explained in the nonverbal (satellite/non-head) part, and the MANNER of motion comes in the adverb:
(31) a. qadamzanăn az tappe bălă raftam. walking from hill up went-1S

I walked up the hill.

3. The main verb indicates both PATH and MANNER of motion:
(32) joqd az surăx-e deraxt birun parid Owl from hole-EZ tree out flew-3S

Owl flew out of the hole.

Another example:
(33) (man) az
(I) from
tappe bălă
davidam.

I ran up the hill.

Although, it may be considered as an incorporated compound verb in which the prepositional disappears after incorporation. (32) may have been as below before incorporation.
(34) joqd $a z$
dăxele-e
surăx $\underline{\underline{b e}}$
birun
hole to
out flew-3s

Both head-framed and non-head framed construction of path (Talmy's verb-framed and satellite-framed patterns) are available in Persian as it is observed above, but except deictic verbs in which path is specified, in other cases, path is expressed mostly in a non-head construction type. The main verb almost expresses manner of motion, and path is mentioned in the non-head part of a clause. Of course, it needs more studies in order to judge and prove whether Persian is a non-head framed (S-Language) or not.

\section{REFERENCES}

[1] Barjasteh, Darab. (1983). Morphology, syntax, and semantics of Persian compound verbs: A lexicalist approach. University of Illionois at Urbana-Champaign, Ph.D dissertation.

[2] Dabir-moghaddam, Mohammad. (1997). Compound Verbs in Persian. Studies in Linguistic Sciences. Volume 27, Number2. PP. 25-59

[3] Dihkhoda, Ali Akbar. (1995). Lughat Name. Tehran University.

[4] Mahootian, S. (1997). Persian, Descriptive Grammars Series. Routledge.

[5] Slobin, Dan.I. (1996). Two ways to travel: Verbs of motion in English and Spanish. Grammatical constructions: Their form and meaning .PP.195-220. Oxford: Clarendon Press.

[6] Talmy, Leonard. (1985). Lexicalization patterns: Semantic structure in lexical forms. Language typology and syntactic description: Grammatical categories and the lexicon. Volume 3. PP.36-149. Cambridge University Press.

[7] Windfuhr, L. G. (1979). Persian grammar: History and State of its Study. Trends in Linguistics. State-of-the-Art Reports 12. The Hague: Mouton Publishers.

Hajar Babai, born in Iran, 1976, has earned her MA in Linguistics at Kobe University, Japan, 2007. She earned a BA degree in Arabic Literature from Imam Sadiq University (ISU) at Tehran, Iran, 1997.

She is now a LECTURER of Japanese Language in the University of Tehran from 2007. She has been teaching Japanese in the Public Education Center of University of Tehran for one year. Her other professional carrier was Interpreting and Translating in International Interpreting Company, Japan, for about 6 years. Also her experience includes teaching Persian to Japanese Learners for International Interpreting Company and Kobe Cross Cultural Center in Japan for a total of 7 years. She has received academic award of Scholarship from MonbuKagakusho (Ministry of Education, Culture, Sports, Science and Technology, Japan, 2003 2007).

She has been a co-author of the paper "Toward a Geotypology of EAT-Expressions in Languages of Asia: Visualizing Areal Patterns through WALS", with Prof. Prashant Pardeshi et al. published in the Journal of the Linguistic Society of Japan, No. 130, December 2006. 